\title{
EVALUASI PEMBELAJARAN DARING TERHADAP MATERI PEMBELAJARAN IPA KELAS IX SMPN 18 KOTA BENGKULU
}

\author{
Anggi Prasani ${ }^{1}$, Desti Herdiyanti ${ }^{2}$, Lisa Puspita ${ }^{3}$, Ahmad Walid ${ }^{4}$ \\ ${ }^{1,2,3,4}$ Pendidikan Ilmu Pengetahuan Alam, Institut Agama Islam Negeri Bengkulu \\ Jl. Raden Fatah Pagar Dewa, Kota Bengkulu 38211 \\ ${ }^{1}$ Email: anggiprasani3@gmail.com \\ 2Email: destiherdianti@gmail.com \\ ${ }^{3}$ Email: lisa03613@gmail.com \\ ${ }^{4}$ Email: ahmadwalid@iainbengkulu.ac.id
}

\begin{abstract}
ABSTRAK
Penelitian ini bertujuan untuk mengetahui kualitas peserta didik melalui metode daring di masa pandemi pada mata pelajaran IPA di SMPN 18 Kota Bengkulu. Metode yang digunakan dalam penelitian ini adalah menggunakan metode kualitatif. Teknik analis data yang digunakan adalah teknik deskriptif kualitatif. Hasil penelitian menunjukkan bahwa materi pembelajaran IPA di SMPN 18 Kota Bengkulu termasuk kategori diatas rata-rata dengan jumlah sebanyak 27 siswa yang mendapat nilai antara 80-85 dan sebanyak 5 siswa yang mendapatkan nilai antara 86-90.
\end{abstract}

Kata Kunci: Evaluasi, Pembelajaran Daring, Pandemi Covid-19.

\section{ABSTRACT}

This study aims to determine the quality of students through online methods during the pandemic in science subjects at SMPN 18 Bengkulu City. The method used in this research is to use qualitative methods. The data analysis technique used is a qualitative descriptive technique. The results showed that the science learning material at SMPN 18 Bengkulu City was in the above average category with a total of 27 students who scored between 80 85 and as many as 5 students who scored between 86-90.

Keywords: Evaluation, Online Learning, Pandemic Covid-19.

\section{PENDAHULUAN}

Untuk mencegah penyebaran covid-19 saat ini, sehingga dihimbau untuk menghentikan acara-acara yang akan mengundang keramaian. Oleh sebab itu pembelajaran tatap muka yang akan mengumpulkan banyak mahasiswa dalam suatu kelas saat proses perkuliahan. Maka dari itu diselenggarakannya skenario yang bisa mencegah hubungan secarah fisik baik mahasiswa maupun dosen (Firman, F \& Rahayu, S. 2020). Sehingga solusi dalam masa pandemi covid-19 yaitu dilakukannya pembelajaran daring. Menurut (Moore, Dickson-Deane \& Galyen. 2011) pembelajaran daring yaitu pembelajaran yang menggunakan jaringan internet dengan aksesibilitas, konektivitas, fleksibilitas, dan kemampuan untuk memunculkan berbagai jenis interaksi pembelajaran. Pembelajaran 
daring bukan hanya dengan internet saja, melainkan aspek penting yaitu lebih aman kita mengenal Learning Management Systems (LMS) (Ali, Gunay Balim. 2009).

Evaluasi merupakan kegiatan yang terencana untuk mengetahui keadaan objek dengan menggunakan instrumen dan hasilnya dibandingkan dengan tolak ukur untuk memperoleh kesimpulan (Thoha. 1990). Nitko dan Brookhat (Rasyid, 2007) mendefinisikan evaluasi sebagai suatu proses penetapan nilai yang berkaitan dengan kinerja dan hasil karya siswa. Evaluasi (penilaian) merupakan suatu proses pengumpulan, pelaporan dan penggunaan informasi tentang hasil belajar siswa yang diperoleh melalui pengukuran dengan tujuan untuk menganalisis atau menjelaskan prestasi siswa dalam mengerjakan tugas-tugas yang terkait dan mengefektifkan penggunaan informasi tersebut untuk mencapai tujuan pendidikan (Puskur, 2002).

Pendidikan sangat berperan penting dalam menentukan suatu perkembangan suatu bangsa dan negara, oleh karena itu kemajuan suatu bangsa bergantung terhadap bangsa itu sendiri dalam menggali sumber daya manusia yang lebih dalam lagi yang berkaitan erat terhadap kualitas pendidikan yang diberikan kepada anggota masyarakat terutama siswa. Seperti dalam UU Republik Indonesia Nomor 20 tahun 2002 tentang Sistem Pendidikan Nasional. Yang tujuan Pendidikan Nasional tersebut dimensi religi yaitu bagian yang terpadu dari tujuan pendidikan nasional (Makhim et al. 2014). Dunia pendidikan guru berperan penting dalam memegang keberhasilan siswa, tugas utama seorang guru adalah mendidik, memantau serta menilai proses hasil pembelajaran. Penilaian dilakukan untuk mengetahui hasil pembelajaran yang telah dilakukan oleh siswa selama proses belajar mengajar yang telah dilakukan. (Anas, Sudijono, 2015). Pendidikan adalah salah satu upaya yang efektif untuk mengatasi suatu keterbatasan kemampuan sehingga orang tua maupun masyarakat sangat berperan penting dalam proses ikut mewujudkan visi maupun misi suatu sekolah. Selain itu pendidikan merupakan bekal utama dalam suatu pengetahuan. (Ali, 2009).

Dalam pembelajaran IPA sebagian besar materi yang berisi deskriptif, dengan metode ceramah yang di gunakan oleh seorang guru. Dalam pembelajarn IPA pengetahuan informasi yang disampaikan menggunakan lisan sehingga keaktifan siswa kurang berperan sehingga untuk berpikir kereatifpun siswa mengalami kesulitan dalam metode ceramah ini, sehingga menimbulkan rasa bosan pada siswa sehingga metode ini kurang efektif. Sehingga dalam proses pembelajaran ini diperlukan pendekatan pembelajaran yang efektif, 
seperti belajaran diluar kelas dalam pembelajaran berbasis pendekatan kontekstual sehingga lebih mempermudah dalam menyampaikan materi sistem reproduksi manusia (Burhan Nurgiyantoro, 2012).

IPA juga merupakan kumpulan pengetahuan tentang objek atau gejala- gejala tentang alam. IPA sebagai proses yang dikenal dngan metode ilmiah. Disamping itu, IPA juga memiliki nilai- nilai ilmiah atau qalue of science yang melekat pada pengetahuan ilmiah (Paramata. 2001). Pembelajaran IPA yang dikembangkan dalam kurikulum 2013 adalah IPA sebagai mata pelajaran integratife science, bukan sebagai pendidikan disiplin ilmu. Pendidikan yang berorientasi aplikasi, pengembangan kemampuan berpikir, kemampuan belajar, rasa ingin tahu, dan pengembangan sikap peduli dan bertangung jawab terhadap lingkungan sosial dan alam (Depdikbud, 2013).

Tujuan pembelajaran IPA adalah untuk mengajarkan peserta didik agar dapat menerapkan apa yang dipelajari dalam kehidupan sehari-hari, maka kemampuan berpikir kritis siswa perlu dilatih sehingga penguasaan suatu konsep oleh siswa tidak hanya berupa hafalan dari sejumlah konsep yang telah dipelajarinya, tetapi mereka mampu menerapkan konsep yang dimilikinya pada aspek yang lain (Susilo, 2010). Keterkaitan kemampuan berpikir kritis dalam pembelajaran IPA Terpadu (Setyorini, 2010) adalah menghubungkan antara apa yang dipelajari dengan bagaimana memanfaatkannya dalam kehidupan seharihari, membantu siswa memecahkan masalah yang dihadapi, dan melatih siswa membuat keputusan yang tepat serta memacu siswa untuk selalu belajar. Tujuan dari penelitian ini yaitu untuk mengetahui kualitas peserta didik melalui metode daring di masa pandemi pada mata pelajaran IPA di SMPN 18 Kota Bengkulu.

\section{METODE PENELITIAN}

Jenis penelitian ini menggunakan penelitian kualitatif. Tujuan penelitian adalah mengambarkan pembelajaran daring yang dilaksanakan di SMPN 18 Kota Bengkulu. Penelitian yang dilakukan pada kelas IX IPA Terhadap guru mata pelajaran IPA, di dalam proses pembelajaran supaya tidak terjadi rantai penyebaran di masa pandemi. Pembelajaran daring dalam penelitian ini adalah pembelajaran dengan media yang di akses menggunakan layanan internet. Penelitian yang dilakukan dengan teknik pengumpulan data yang digunakan adalah: (1) observasi, (2) wawancara, (3) Menganalisis soal (Miles \& Huberman, 1994). Pengumpulan data adalah prosedur yang sistematis dan standar untuk 
memperoleh data atau informasi yang diperlukan. Adapun teknik pengumpulan data yang digunakan dalam penelitian ini meliputi sebagai berikut: 1.Wawancara Teknik wawancara dalam penelitian ini dilakukan. Wawancara dilakukan dengan bertanya langsung kepada informan untuk menggali dan mendapatkan informasi mengenai situasi pembelajaran IPA dengan menggunakan metode daring. Wawancara dengan informan dilakukan secara online. 2.Observasi merupakan suatu teknik pengumpulan data atau informasi dengan cara pengamatan terhadap kegiatan yang sedang berlangsung. Observasi dilakukan untuk memperoleh gambaran riil suatu peristiwa atau kejadian untuk menjawab pertanyaan penelitian. Observasi dilakukan dengan cara mengamati secara langsung obyek penelitian. Adapun informasi yang ingin diperoleh dari hasilobeservasi yaitu data mengenai kondisi lingkungan pembelajaran IPA pada SMPN 18 Kota Bengkulu yang berkaitan dengan penarapan metode daring.

Penelitian kualitatif adalah penelitian yang mengumpulkan data yang sudah dianalisis. Kualitatif ini dipandang relevan untuk mengkondisikan yang terjadi pada pembelajaran daring di masa pandemi. Jenis data yang dikumpulkan merupakan hasil penelitian dari observasiserta wawancara. Subjek dan objek dalam penelitian ini adalah mahasiswa dengan guru di jurusan IPA saling berinteraksi melakukan observasi tanya jawab (Sugiyono, 2009).

\section{HASIL DAN PEMBAHASAN}

Berdasarkan hasil wawancara dengan dan guru mata pelajaran IPA terkait dengan penerapan metode pembelajaran daring selama wabah Covid-19 yaitu: dari penelitian yang kami lakukan di SMPN 18 Kota Bengkulu, pembleajran yang di lakukan di SMPN 18 Kota Bengkulu selama pandemi ini dilakukan pembelajaran daring dan di masa pandemi ini menggunakan google clasroom sebagai alat pembelajaran, satu minggu sekali sebagian siswa "kurang mampu" 10\% siswa datang ke sekolah untuk mengambil tugas kepada guru mata pelajarannya masing-masing untuk dikerjakan di rumah. Selanjutnya tugas-tugas yang diberikan guru di kumpul melalui google clasroom karena kurangnya ekonomi siswa guru memberi solusi tersebut supaya tidak terlalu membebani siwa untuk belajar dengan hasil yang diinginkan.

Evaluasi yang dilakukan di SMPN 18 Kota Bengkulu ini dilakukan diakhir pembelajaran, karena terkendala waktu selama pandemi sehingga evaluasi pembelajaran 
tidak dilakukan setiap materi yang diberikan, tetapi evaluasi ini hanya dilakukan diakhir sub materi yang diberikan. Karena kurangnya fasilitas siswa yang kurang memadai seperti laptop, selanjutnya terkendala kuota sehingga diberikan subsidi dari KEMENDIKBUD dan Pemerintah Daerah. Kendala selanjutnya yaitu jaringan di setiap daerah yang kurang mendukung.

Berdasarkan hasil penelitian yang diperoleh dari beberapa informan di atas menunjukkan bahwa metode pembelajaran daring ditengah wabah covid-19 khusus mata pelajaran IPA menimbulkan masalah tersendiri yang dirasakan baik oleh guru mata pelajaran maupun peserta didik. Hal itu disebabkan oleh sulitnya menjelaskan rumus dan materi perhitungan tanpa melalui tatap langsung antara pengajar dan peserta didik. Susahnya menyampaikan materi berupa rumus perhitungan yang dirasakan oleh guru mata pelajajran IPA berbanding lurus dengankesulitan yang dirasakan oleh peserta didik dalam memahami materi pelajaran IPA.

Selama pandemi ini pembelajaran yang dilakukan dianggap kurang evektif karena waktunya yang terbatas, dalam pembelajaran daring pemahaman siswa dalam proses pembelajaran berbeda-beda ada yang mudah memahami pembelajaran dan ada juga yang terkendala dalam proses pemahaman, tetapi di jaman era digital sekarang sehingga siswa belajar tidak hanya melalui guru tetpi juga bisa belajar melalui aplikasi seperti You Tube, Google dan sebagainya, hal yang membedakan pembelajaran tatap muka dan daring ini yaitu kurangnya kemistri dan kedekatan antara guru dan siswa. Selama pandemi tidak ada pembelajaran yang dilakukan di luar sekolah jika pembelajaran dilakukan di luar sekolah efeknya kepada siswa, karena jika di dalam keramaian dikhawatirkan banyak siswa yang tidak mematuhi protokol kesehatan, jadi selama pendemi tidak ada pertemuan tatap muka, dalam artian hanya secara daring.

Selain faktor susahnya menyampaikan materi oleh guru, dan susahnya memahami materi oleh peserta didik, masalah lain yang dihadapi oleh informan yaitu jaringan yang kadang terputus sehingga proses belajar tidak dapat dilakukan secara lancar. Selain faktor jaringan, keterbatasan sebagian peserta didik dan orang tua peserta didik dalam membeli data internatan menjadi salah satu kendala sehingga proses pembelajaran daring kurang efektif. Dengan demikian, penerapan aplikasi Zoom maupun aplikasi yang menggunakan data internetan tidak dapat diterapkan dalam prose pembelajaran IPA pada SMPN 18 Kota Bengkulu. 
Dari berbagai faktor diatas, salah satu langkah yang ditempuh oleh guru mata pelajaran IPA agar proses pembelajaran tetap berlangsung dan tidak terlalu memberatkan peserta didik yaitu dengan menggunakan aplikasi zoom. Pemilihan aplikasi zoom disebabkan oleh aplikasi tersebut tetap dapat diaksesoleh peserta didik meskipun data internetan telah habis. Sehingga dalam mengirim materi pelajaran maupun tugas guru lebih memilih menggunakan messenger demi meringankan beban peserta didik maupun orang tua peserta didik. Terlepas dari kendala yang dihadapi oleh guru mata pelajaran IPA tersebut di atas, guru tersebut tetap berusaha memberikan yang terbaik kepada peserta didiknya agar peserta didik tersebut tetap menerima materi meskipun tidak semaksimal ketika proses pembelajaran dilaksanakan dalam lingkungan sekolah. Salah satu cara yang dilakukan guru mata pelajaran IPA yaitu memberi materi secara bertahap dengan menggunakan bahasa yang sederhana disertai dengan contoh sesederhana mungkin. Selanjutnya dalam pemberian tugas, guru memberikan tenggat waktu yang dianggap sesuai dengan kebutuhan peserta didik. Pemberian tenggat waktu tersebut tidak terlalu lama karena dikhawatirkan peserta didik lupa dan lalai akan tugasnya.

Tabel 1. Tabel analisis nilai kelas IX SMPN 18 Kota Bengkulu

\begin{tabular}{ccc}
\hline No & Nilai & F \\
\hline 1 & $80-85$ & 27 \\
\hline 2 & $86-90$ & 5
\end{tabular}

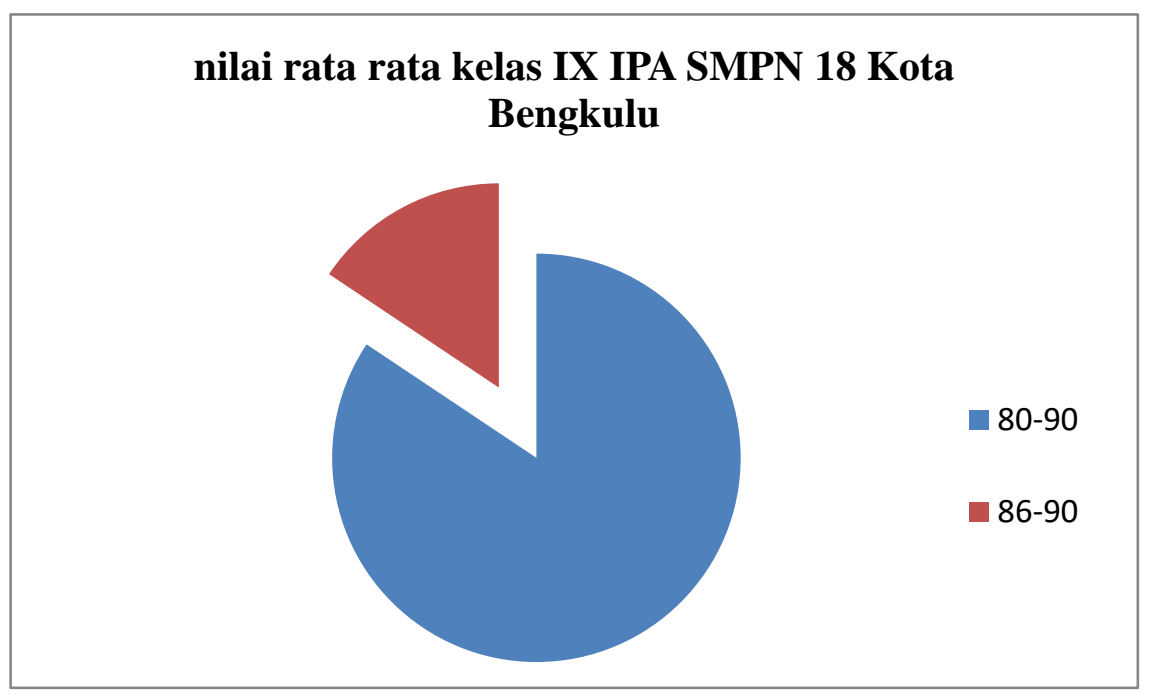

Grafik 1. analisis nilai kelas IX SMPN 18 Kota Bengkulu 
Dari data di atas menunjukkan bahwa rata-rata kualitas nilai pada kelas IX mata pelajaran IPA di SMPN 18 Kota Bengkulu terbilang bagus, karena materi yang disampaikan tidak terlalu sulit dan metode yang digunakan daring lebih mempermudah siswa mendapatkan sumber pembelajaran.

Evaluasi yang dilakukan di SMP Negeri 18 Kota Bengkulu ini dilakukan di akhir pembelajaran, karena terkendala waktu selama pandemi sehingga evaluasi pembelajaran tidak dilakukan setiap materi yang diberikan, tetapi evaluasi ini hanya dilakukan di akhir sub materi yang diberikan. Karena kurangnya fasilitas siswa yang kurang memadai seperti laptop, selanjutnya terkendala kuota sehingga diberikan subsidi dari KEMENDIKBUD dan Pemerintah Daerah. Kendala selanjutnya yaitu jaringan di setiap daerah yang kurang mendukung.

\section{SIMPULAN}

Berdasarkan hasil data di atas dapat disimpulkan bahwa berdasarkan dari data informan diatas menunjukkan bahwa pembelajaran daring dianggap kurang evektif, tetapi walau demikian guru bisa mengsiasati pembelajaran dengan menggunakan aplikasi seperti Zoom atau juga bisa menggunakan You Tube dan Google sebagai sumber pengetahuan sehingga nilai yang didapat di SMPN 18 Kota Bengkulu mencapai rata-rata nilai 80-85 terdapat 27 siswa dan nilai 86-90 terdapat 5 siswa. Dari tabel dan grafik menunjukkan bahwa analisis nilai pada kelas IX mata pelajaran IPA di SMPN 18 Kota Bengkulu terbilang bagus, karena materi yang disampaikan tidak terlalu sulit dan metode daring yang digunakan juga mempermudah siswa mendapatkan sumber pembelajaran.

\section{SARAN}

Peneliti menyadari sepenuhnya jika artikel ini masih banyak kekurangan, oleh karena itu untuk memperbaiki artikel ini, kritik dan saran yang bersifat membangun dari para pembaca sangatlah peneliti harapkan.

\section{DAFTAR PUSTAKA}

Ali, M. 2009. Pendidikan untuk Pembangunan Nasional Menuju Bangsa Indonesia yang Mandiri dan Berdaya Saing Tinggi. Bandung: Imtima. 
Balım, A., G. (2009). The Effects of Discovery Learning on Students' Success and Inquiry Learning Skills. Egitim Arastirmalari Eurasian Journal of Educational Research, 35, $1-20$.

Setyorini, U. 2010. Penerapan Model Problem Based Learning Untuk Meningkatkan Kemampuan Berpikir Kritis Siswa SMPN 24 Semarang Pada Sub Pokok Bahasan GLBB. Skripsi. Semarang: Universitas Negeri Semarang.

Susilo, A. B. 2012. Pengembangan Model Pembelajaran IPA Berbasis Masalah Untuk Meningkatkan Motivasi Belajar dan Berpikir Kritis Siswa SMP. Unnes Science Education Journal, 1(1) 12-20.

Sudijono, A.2015. Pengantar Evaluasi Pendidikan. Jakarta: PT. Raja Grafindo Persada.

Nurgiyantoro, B. 2012. Penilaian Pembelajaran Bahasa Berbasis Kompetensi. Yogyakarta: BPFE-Yogyakarta.

Depdikbud. 2013. Materi pelatihan guru implementasi kurikulum 2013 SMP, MTs Ilmu Alam (pp.1-366). Jakarta: Badan Pengembangan Sumber Daya Ma-nusia Pendidikan dan Kebudayaandan Penjaminan Mutu Pendidikan, Ke-mendikbud.

Firman, F\& Rahayu, S. 2020. Pembelajaran Online di Tengah Pandemi Covid-19. Indonesian Journal of Educational Science (IJES), 2(2), 81-89.

Makhin, A.dkk. 2014. Penggunaan Bahan Ajar Berbasis Imtaq dalam Meningkatkan Hasil Belajar Siswa pada Pokok Bahasan Sistem Reproduksi Manusia di Kelas XI IPA SMA Negeri 1 Astanajapura Kabupaten Cirebon. Journal Sains Scientiae Educatia, 3(1),89-105.

Moore, J. L., Dickson-Deane, C., \& Galyen, K. 2011. E-Learning, online learning, and distance learning environments: Are they the same? Internet and Higher Education.

Paramata,Y. 2001. Pengembangan model so-sialisasi inovasi dan supervisi pembelajaran ilmu pengetahuan alam. (Disertasi Dok-tor. Universitas Pendidikan Indone-sia). Hal 2.

Puskur. 2002. Kurikulum Berbasis Kompetensi. Penilaian Berbasis Kelas. Jakarta: Balitbang Depdiknas.

Rasyid, Harun dan Mansur. 2007. Penilaian Hasil Belajar. Bandung: CV. Wacana Prima.

Thoha, M. Chabib. Teknik Evaluasi Pendidikan, PT. Raja Grafindo: Jakarta 1990.

Wand, Edwin, and Brown, Gerald W. 1957. Essentials of Educational Evaluation, New York : Holt Rinehart and Winston. 